\title{
IMPLEMENTATION THINK TALK WRITE STRATEGY TO LEVEL IT PROBLEM SOLVING ABILITY MATHEMATICS AND SELF CONFIDENT JUNIOR HIGH SCHOOL STUDENTS
}

\author{
Elah Hayati ${ }^{1}$ \\ ${ }^{1}$ IKIP Siliwangi, Bandung \\ 1elahhayati201@gmail.com \\ Received: June, 2018; Accepted: June, 2018
}

\begin{abstract}
This writing is result from research that have go to to to study the leveling of problem solving-ability mathematics and self confident student mediating school first with strategy think talk write to be compared ordinary studying. This research to design experiment that use it experiment group method and control group pretes-postes. Population in research this is entire student in a Yunior High School in Kabupaten Subang with class student sample VII E and VII F SMP mentioned. the test Type that to be used is the written test in form decomposing. Postes's quantitative data to be based to through test $\underline{\mathbf{t}}$ to normal data and test Mann Whitney to data not normal levely significant $\quad \alpha=0,05$ be obtained that the archievment of problem solving-ability mathematics and self confident student mediating school first groups experiment better than control group. Gain second groups be analyzed to through test-t to normal data and test Mann Whitney to data not normal be obtained that the leveling of problem solving-ability mathematics and self confident student mediating school first groups experiment better than control group. To be concluded that studying with strategy think talk write influency better to problem solving ability mathematics and self confident $\underline{t}$ student VII Yunior High School class than problem solving ability mathematics and self confident student who use it ordinary studying.
\end{abstract}

Keywords: Strategy think talk write, the ability of mathematics problem-solving, self confident

\begin{abstract}
Abstrak
Tulisan ini merupakan hasil dari penelitian yang telah sampai ke untuk mempelajari leveling kemampuan pemecahan masalah matematika dan self confidence siswa sekolah menengah pertama dengan strategi think talk write dibandingkan pembelajaran biasa. Penelitian ini untuk merancang eksperimen yang menggunakan metode kelompok eksperimen dan kelompok kontrol pretes-postes. Populasi dalam penelitian ini adalah seluruh siswa di SMP Negeri di Kabupaten Subang dengan sampel siswa kelas VII E dan VII F SMP yang disebutkan. Tes Jenis yang akan digunakan adalah tes tertulis dalam bentuk pembusukan. Data kuantitatif postes yang akan didasarkan melalui uji t untuk data normal dan uji Mann Whitney ke data tidak normal levely signifikan $\alpha=0,05$ diperoleh bahwa archievment dari pemecahan masalah kemampuan matematika dan percaya diri siswa siswa sekolah menengah pertama kelompok percobaan lebih baik daripada kelompok kontrol. Gain kelompok kedua dianalisis melalui uji-t untuk data normal dan uji Mann Whitney ke data yang tidak normal diperoleh bahwa leveling kemampuan pemecahan masalah matematika dan self confidence siswa yang memediasi kelompok pertama sekolah bereksperimen lebih baik daripada kelompok kontrol. Dapat disimpulkan bahwa belajar dengan strategi berpikir talk write influency lebih baik terhadap kemampuan pemecahan masalah matematika dan percaya diri siswa kelas VII SMP Yunior daripada kemampuan pemecahan masalah matematika dan percaya diri siswa yang menggunakannya belajar biasa.
\end{abstract}

Kata kunci: Strategi think talk write, kemampuan pemecahan masalah matematika, percaya diri

How to Cite: Hayati, E. (2018). Implementation Think Talk Write Strategy to Level IT Problem Solving Ablity Mathematics and Self Confident Junior High School Students. JIML, $1(2), 67-74$. 
68 Hayati, E. Implementation Think Talk Write Strategy to Level IT Problem Solving Ablity Mathematics and Self Confident Junior High School Students.

\section{INTRODUCTION}

Its important study problem solving in the pinned up mathematics inside KTSP (2006) that is mathematics studying aim its between to understand mathematics concept, his hookness, to application it in problem solving. Utami Munandar (2002) brought up that problem solving is the attitudy studying creative, problem solution mathematicaly can to assist the students to level it power their analitis and can to help them in to apply it power mentioned to all kind of situation. When student communicate it concept so needed feel the body believe (self confident ). If student have feel the body believe so he would can to submit it fruit his think. Although to student's initially forced to to talk but after he is succeed to bring up it the opinion so will emerge the body's believing. After to time-time to submit it idea so student would to has believing the strong body until he is brave appear in front public.

The Studying of mathematics problem-solving to has two meanings, that is: as approach and as aim of the studying is brought up by Branca (Sumarmo, 2005) As an studying approach that is the basy studying approach problem, problem solving is approach that dish it contexttual problem as beginning spot and then according to to phase to find back ( reinvention ) and to understand material/concept/Mathematics principle. As studying aim or ability that must be reached after studying that is ability thought mathematics, mathematics problem solving as a covering process some activities that is to identificate element enoughness to problem solution, to choose and execute it strategy to to finish it problem, to execute it calculation, and to interpret solution in problem from the beginning and to investigate solution justification.

To break it problem not just is a target study mathematics, but all at once is main tool to to do study that to be mentioned by NCTM (2000). By because that, problem solving ability become mathematics studying focus in all level, from elementary school until high. The Ability of mathematics problem-solving that in mean in this research is is ability finish it problem that not routine with to understand problem, to planned it solution, to finish it problem according to plan, and to do checking back in all the step that have been done.

To to level it problem solving ability and self confident not easy. With method the to teach that the most of ordinary in do teacher that is the less lecture method can to dig ability and self confident student. the flowery mathematics studying Pattern in Indonesia at this time, is conventional studying that yet to prosecute undefined in his studying activity process. Until many students who consider that mathematics is lesson that to daunt it and difficult to student's to be controlled. Student who own the true body concept will has feel the body believe strong ones because what is exist in his think is something pricy ones proper ones to to be brought up to other people. To join in Rahmat (2000) body believing can to be meaned as a believing in body self that to be have by everyone in its life also people people been mentioned to view the body intactly with to refer to body concept. To join in opinion Angelis (2003), believe body to begin from will to body self, to to do everything that we want it and need it in life. Believe body builded from body conviction self, until we are able to face challenging of life whatever with to make something.

Because got problem that is existence between realita with idealita in teacher yet to realize its important of ability to thought mathematics and its necessary to level it self confident student so there is solution to the mentioned problem that is think talk strategy write. Strategy think talk write is a plan about potency usage and the tool that exist to to level it effectivity of instruction, to join in Slameto (Yatim Riyanto, 2009: 131). The step of problem solving-solution mentioned can be supported with strategy usage TTW (Think-Talk-Write) that can to level it the mathematical problem solving-ability to student. After student can to break it a mathematical problem to 
phase second and last in TTW's strategy (Think-Talk-Write), that is discussion with friend in small group and to write it problem solving, to be expected student level feel the body believe and interest them in mathematics studying.

With to see phase strategy process think-talk-write that is to process student's talk in prosecute to to talk to communicate it what was had he thought in discussion and to share idea (sharing) with his friend before to write. Mathematics is the attitudy knowledge structured and systematic until a studying material become prerequisite material to to study the other studying material. If prerequisite material yet to be controlled so student would to feel difficulty to study studying material its follower. By because that ability early important mathematics to to be tested so that seen student's ready to accept a studying material.

\section{METHOD}

The research method that to be used is experiment where 2 subjec's sample in choose from 2 class that is experiment class in class VII F and control's class in class VII G. With its design as followed:

$$
\begin{array}{ccc}
0 & \mathrm{X} & 0 \\
\hdashline 0 & & 0
\end{array}
$$

Information:

$0 \quad$ : beginning test (pretes) = end test (postes) the ability of mathematics problem-solving and communicate mathematics with matter as equal as ones in form matter essay

$\mathrm{X} \quad$ : Treatment to experiment class to use it strategy think talk write

------ : Show that sample sample not randomly because to be used experiment quasi

\section{RESULTS AND DISCUSSION}

\section{Results}

Result complete data research can be seen to attaching, whereas briefy to be presented to table 1 under this.

\begin{tabular}{|c|c|c|c|c|c|c|c|c|c|c|}
\hline \multirow[b]{2}{*}{$\begin{array}{c}\text { Mathematic } \\
\text { Ability }\end{array}$} & \multirow[b]{2}{*}{ KAM } & \multirow{2}{*}{$\begin{array}{c}\bar{x} \\
\text { Dan } \\
\text { S }\end{array}$} & \multicolumn{4}{|c|}{ Eksperiment (STTW) } & \multicolumn{4}{|c|}{ Control (OS) } \\
\hline & & & $\begin{array}{c}\text { Pretes } \\
(\%)\end{array}$ & $\begin{array}{c}\text { Postes } \\
(\%)\end{array}$ & (g) & $\mathbf{n}$ & $\begin{array}{c}\text { Pretes } \\
(\%)\end{array}$ & $\begin{array}{c}\text { Postes } \\
(\%)\end{array}$ & (g) & $\mathbf{n}$ \\
\hline \multirow{12}{*}{ PSAM } & \multirow{3}{*}{ High } & $\bar{x}$ & 1,50 & 13,55 & 0,51 & 4 & 1,40 & 11 & 0,41 & 4 \\
\hline & & & $6 \%$ & $54,2 \%$ & & & $5,60 \%$ & $44,00 \%$ & & \\
\hline & & $S$ & 1,91 & 3,11 & 0,05 & & 0,55 & 1,73 & 0,05 & \\
\hline & \multirow{3}{*}{ Medium } & $\bar{x}$ & 1,40 & 12,33 & 0,46 & 15 & 1,43 & 9,37 & 0,34 & 16 \\
\hline & & & $5,60 \%$ & $49,32 \%$ & & & $5,72 \%$ & $37,48 \%$ & & \\
\hline & & $S$ & 0,63 & 1,99 & 0,05 & & 0,94 & 1,31 & 0,01 & \\
\hline & \multirow{3}{*}{ Low } & $\bar{x}$ & 1,16 & 10,20 & 0,37 & 10 & 1,22 & 6,89 & 0,24 & 9 \\
\hline & & & $4,64 \%$ & $40,80 \%$ & & & $4,88 \%$ & $27,56 \%$ & & \\
\hline & & $\mathrm{S}$ & 1,03 & 0,98 & 0,00 & & 0,44 & 2,18 & 0,07 & \\
\hline & \multirow{3}{*}{ Total } & $\bar{x}$ & 1,31 & 11,76 & 0,44 & 29 & 1,31 & 8,83 & 0,32 & 29 \\
\hline & & & $5,24 \%$ & $47,04 \%$ & & & $5,24 \%$ & $35,32 \%$ & & \\
\hline & & $\mathrm{S}$ & 1,00 & 2,20 & 0,05 & & 0,76 & 2,22 & 0,06 & \\
\hline \multirow{3}{*}{ SC } & \multirow[t]{3}{*}{ High } & $\bar{x}$ & & 61,00 & & 4 & & 52,25 & & 4 \\
\hline & & & & $76,25 \%$ & & & & $65,31 \%$ & & \\
\hline & & $\mathrm{S}$ & & 4 & & & & 4,99 & & \\
\hline
\end{tabular}

Table 1. The Recapitulation of Test-Result Problem Solving Mathematic and Self Confident Student 
70 Hayati, E. Implementation Think Talk Write Strategy to Level IT Problem Solving Ablity Mathematics and Self Confident Junior High School Students.

\begin{tabular}{|c|c|c|c|c|c|}
\hline \multirow[t]{2}{*}{ Medium } & $\bar{x}$ & $\begin{array}{c}54,6 \\
68,25 \% \\
\end{array}$ & 15 & $\begin{array}{c}53 \\
66,25 \% \\
\end{array}$ & 16 \\
\hline & $\mathrm{S}$ & 5 & & 3,90 & \\
\hline \multirow[t]{2}{*}{ Low } & $\bar{x}$ & $\begin{array}{c}55,10 \\
68,87 \%\end{array}$ & 10 & $\begin{array}{l}53,56 \\
66,95\end{array}$ & 9 \\
\hline & $\mathrm{S}$ & 3,94 & & 4,64 & \\
\hline \multirow{2}{*}{ Total } & $\bar{x}$ & 40,35 & 29 & 25,65 & 29 \\
\hline & $\mathrm{S}$ & 25,57 & & 19,40 & \\
\hline \multicolumn{5}{|c|}{ Maximal Scor Ideal KPMM=25 } & \\
\hline \multicolumn{5}{|c|}{ Maximal Scor Ideal SC $=80$} & \\
\hline
\end{tabular}

Notes :
1. PSAM : Problem Solving Ability Mathematics
2. STTW : Strategy Think Talk Write
3. SC : Self Confident
4. OS : Ordinary Studying

Table 2. Processing Result and Test According to Statictic the Ability of Mathematics Problem-Solving

\begin{tabular}{|c|c|c|c|c|c|c|}
\hline \multirow[b]{2}{*}{ Aspect } & \multicolumn{2}{|c|}{ Average } & \multirow{2}{*}{$\begin{array}{c}\text { Statictic } \\
\text { Type }\end{array}$} & \multirow[b]{2}{*}{ Sign. } & \multirow[b]{2}{*}{$\begin{array}{c}\text { Conclusi } \\
\text { on }\end{array}$} & \multirow[b]{2}{*}{ Information } \\
\hline & $\begin{array}{l}\text { For } \\
\text { mer }\end{array}$ & Control & & & & \\
\hline Pretes & 1,31 & 1,31 & $\begin{array}{c}\text { Mann } \\
\text { Whitney }\end{array}$ & 0,784 & $\begin{array}{c}\text { Ho be } \\
\text { accepted }\end{array}$ & $\begin{array}{c}\text { Not got archievment } \\
\text { difference PSAM } \\
\text { between STTW's } \\
\text { Studying with OS }\end{array}$ \\
\hline Postes & $\begin{array}{c}11,7 \\
6\end{array}$ & 8,83 & $\begin{array}{c}\text { Mann } \\
\text { Whitney }\end{array}$ & 0,000 & $\begin{array}{l}\text { Ho be } \\
\text { refused }\end{array}$ & $\begin{array}{l}\text { Got archievment } \\
\text { difference PSAM } \\
\text { between STTW's } \\
\text { Studying with OS }\end{array}$ \\
\hline $\begin{array}{c}\mathrm{N}- \\
\text { Gain }\end{array}$ & 0,44 & 0,32 & Test $\mathrm{t}$ & 0,958 & $\begin{array}{l}\text { Ho be } \\
\text { refused }\end{array}$ & $\begin{array}{c}\text { Got leveling } \\
\text { difference PSAM } \\
\text { between STTW's } \\
\text { Studying with OS }\end{array}$ \\
\hline
\end{tabular}

Table 3. Processing Result and Test Statictic of Association Deliver Ability

\begin{tabular}{ccccccc}
\hline $\begin{array}{c}\text { Association } \\
\text { deliver } \\
\text { ability }\end{array}$ & $\begin{array}{c}\text { Statictic } \\
\text { Type }\end{array}$ & Sign. & $\begin{array}{c}\text { Conclusi } \\
\text { on }\end{array}$ & $\begin{array}{c}\text { Koef. } \\
\text { Konti- } \\
\text { ngensi }\end{array}$ & $\begin{array}{c}\text { Associati } \\
\text { on Degree }\end{array}$ & $\begin{array}{c}\text { Interpretati } \\
\text { on }\end{array}$ \\
\hline $\begin{array}{c}\text { PSAM and } \\
\text { SC }\end{array}$ & $\begin{array}{l}\text { Chi- } \\
\text { Square }\end{array}$ & 0,823 & $\begin{array}{c}\text { Ho be } \\
\text { accepted }\end{array}$ & - & - & $\begin{array}{c}\text { Not got } \\
\text { association }\end{array}$ \\
\hline
\end{tabular}

\section{Discussion}

To be based to Table 1 in on can to be brought up some conclusions that related with comprehension ability and logicing mathematics SMP's student, that is :

a. According to entirely skor ability pretes pe problem solving student's mathematics SM P to class that his studying with strategy think talk write not different significantly with class that use it ordinary studying 
b. To archievment of ability problem solving student's mathematics SMP that using his studying strategy think talk write and ordinary studiying to show difference. According to entirely, archievment of ability problem solving student's mathematics SMP that using his studying strategy think talk write with average 11,76 higher to be compared that his studying to use it ordinary studying with average 8,83 .

c. To be based KAM student, seen that more and more high KAM so more and more high as well archievment of ability pe problem solving student's mathematics SMP.

d. To KAM high, KAM medium and KAM low, the archievment of problem solving-ability student's mathematics SMP that his studying use it strategy think talk write higher to be compared that his studying use it ordinary studying.

e. To KAM high, KAM medium and KAM low n- Gain ability student's mathematics problem solving SMP that his studying use it strategy think talk write higher to be compared that his studying use it ordinary studying.

To be based of Table 2 data processing-result and testing according to statistic with test normality, test homogenitas, and test $t$ or test $t$ ' if not homogen also test Mann Whitney if data doesn't distribute normal that had be done to data self confident student's mathematics, be obtained result as to followed:

The to be based of data processing-result and testing according to statistic with test normality, test homogenitas, and test $t$ or test $t$ ' if not homogen also test Mann Whitney if data doesn't distribute normal that had be done to the data of problem solving-ability student's mathematics, be obtained result as to followed table 2 .

Research result to research result to be based can be knowing that the ability of mathematics problem-solving student can to level with strategy think talk write. Average solving pretes ability mathematics problem not table to be based different in on. With class other word experiment and class control has ability the same early to Set of material.

Be seen from scor average test finally the class that be taught with strategy think talk write better if to be compared with class who get ordinary studying. this Matter way with meeting to research (2009) that said that the mathematics studying that to be began with pouring of the ideas from student individualy about answering possibility and or solution steps on the problems that to be gave, make small notes, discussion in group with to appear it conversation various answering possibility, to write it back discussion result and to be ended with presentation can to level it the ability of mathematics problem-solving student to be compared with ordinary studying. This Matter also way with meeting Ramdhianingsih (2016), Deswita (2016), Caroko (2017) that studying with to use it strategy think talk write can to level it the ability of mathematics problem-solving.too be based can be knowing that the ability of mathematics problem-solving student can to level with strategy think talk write. Average solving pretes ability mathematics problem not table to be based different in on. With class other word experiment and class control has ability the same early to set of material.

Be seen from scor average test finally the class that be taught with strategy think talk write better if to be compared with class who get ordinary studying. This matter way with meeting to research that said that the mathematics studying that to be began with pouring of the ideas from student individualy about answering possibility and or solution steps on the problems that to be gave, make small notes, discussion in group with to appear it conversation various answering possibility, to write it back discussion result and to be ended with presentation can to level it the ability of mathematics problem-solving student to be compared with ordinary 
72 Hayati, E. Implementation Think Talk Write Strategy to Level IT Problem Solving Ablity Mathematics and Self Confident Junior High School Students.

studying. this Matter also way with meeting Ramdhianingsih (2016), Deswita (2017), Caroko (2017) that studying with to use it strategy think talk write can to level it the ability of mathematics problem-solving.

Association between problem solving ability with self student's confident the to be based table 3 of data processing-result testing and staticticy with test association deliver the ability of mathematics problem-solving and self confident student. From table in on also seen not got association between the ability of student problem-solving with self confident student.

\section{CONCLUSION}

Leveling problem solving ability and self confident for student Yunior High Scool that his studying to use it Strategy Think Talk Write better than that his studying use it ordinary Studying. But not got association between the ability of student problem-solving with self confident student.

\section{REFERENCES}

Angelis. (2003). Pengertian Kepercayaan Diri. [Online] http://belajarpsikologi.com/2017/08/10/pengertian-kepercayaan-diri/. [Diakses: 10 Maret 2017]

Arikunto, S. (2010). Prosedur Penelitian.Jakarta: Rineka Cipta.

Caroko, Windu. (2017). Meningkatkan Kemampuan Komunikasi dan Pemecahan Masalah serta Disposisi Matematik siswa SMP Melalui Pendekatan Think Talk Write. Tesis pada Pascasarjana Sekolah Tinggi Keguruan dan Ilmu Pendidikan (STKIP) Siliwangi Bandung: Tidak Diterbitkan.

Deswita, Vivi. (2017). Peningkatan Kemampuan Pemahaman dan Komunikasi serta Kemandirian BelajarMatematik Siswa SMP Melalui Strategi Think Talk Write. Tesis pada Pascasarjana Sekolah Tinggi Keguruan dan Ilmu Pendidikan (STKIP) Siliwangi Bandung: Tidak Diterbitkan.

Fajar, M.(2009). Ilmu Komunikasi (Teori dan Praktek). Jakarta: Graha Ilmu.

Hamzah, A. (2014). Evaluasi Pembelajaran Matematik. Jakarta: Raja Grafindo Persada.

http://suaidinmath.wordpress.com/2017/03/8/strategi-pembelajaran-think-talk-write. 8 Maret $\underline{2017}$

http://eprints.uny.ac.id/2017/03/8/Novita Yuanari-07301244091.pdf. 8 Maret 2017

http://mellyirzal.blogspot.co.id/2017/03/09/strategi-pembelajran-think-talk-write.html. 9 Maret 2017

https://mahmuddin.wordpress.com/2010/02/18/menciptakan-lingkungan-pembelajaran-yangkondusif/(4 Mei 2017)

http://www.gurukelas.com/2011/10/pentingnya-konsentrasi-bagi-siswa.htm(4 Mei 2017) 
Irsanto, Iko. (2017). Meningkatkan Kemampuan Pemahaman dan Komunikasi Matematis serta Motivasi Belajar Siswa SMP Melalui Strategi Pembelajaran Think Talk Write (TTW). Tesis pada Pascasarjana Sekolah Tinggi Keguruan dan Ilmu Pendidikan (STKIP) Siliwangi Bandung: Tidak Diterbitkan.

KTSP, Tim. (2006). Kurikulum Tingkat Satuan Pendidikan. Jakarta: Depdiknas.

Maya, R. (2011).Pengaruh Pembelajaran dengan Metode Termodifikasi terhadap Pencapaian Kemampuan Pemahaman dan Pembuktian Matematik Mahasiswa. Disertasi pada SPS UPI.Bandung:Tidak diterbitkan

Munandar, S.C.,Utami. (2002).Kreatifitas dan Keterbakatan: Strategi Mewujudkan Potensi Kreatif dan Berbakat. Jakarta: Gramedia Pustaka Utama.

NCTM. (2000). Currirulumand Evaluastion Standard for School Mathematics Education. Reston. VA : NCTM

Riyanto, Yatim. Model Pembelajaran Think Talk Write. [Online]

https://www.slideshare.net/2017/03/09/anatahara/model-pembelajaran-ttw . [Diakses: 9 Maret 20171

Rahmat.(2000). Pengertian Kepercayaan Diri. [Online] http://belajarpsikologi.com/2017/08/10/pengertian-kepercayaan-diri/. [Diakses: 10 Maret 2017]

Ramdhianingsih, Ima, N. (2016). Peranan Strategi Think Talk Write untuk Mengembangkan Kemampuan Pemecahan Masalah dan Bepikir kritis matematik serta Self Concept Siswa SMK di Kota Cimahi.Tesis pada Pascasarjana Sekolah Tinggi Keguruan dan Ilmu Pendidikan (STKIP) Siliwangi Bandung: Tidak Diterbitkan.

Riduan. (2009). Belajar Mudah penelitian untuk Guru-Karyawan dan Peneliti Pemula. Bandung: Alfabeta.

Russeffendi, H.E.T. (2005). Dasar-Dasar Penelitian Pendidikan dan Bidang Non Eksak lainnya. Bandung: Tarsito

Sudarini, Imas. (2016). Peningkatan Kemampuan Penalarandan Komunikasi Matematik serta Motivasi Belajar Siswa SMA Melalui StrategiThink Talk-Write. Tesis pada Pascasarjana Sekolah Tinggi Keguruan dan Ilmu Pendidikan (STKIP) Siliwangi Bandung: Tidak Diterbitkan.

Suherman, Erman. (2003). Strategi Pembelajaran Matematika Kontemporer. Bandung: Jurusan Pendidikan Matematika Universitas Pendidikan Indonesia.

Suherman, E. (2001). Strategi Pembelajaran Matematika Kontemporer. Bandung: JICA-UPI

Somantri, A dan Muhidin,S.A. (2006). Aplikasi Statistika dalam Penelitian.Bandung: CV. Pustaka Setia. 
74 Hayati, E. Implementation Think Talk Write Strategy to Level IT Problem Solving Ablity Mathematics and Self Confident Junior High School Students.

Sumarmo, Utari. (2015). Kumpulan Makalah Berpikir dan Disposisi Matematik serta Pembelajarannya. Bandung: Jurusan Pendidikan Matematika FPMIPA UPI. 